\title{
DETECTION OF SOME OF VIRULENCE GENES IN SALMONELLA KENTUCKY ISOLATED FROM POULTRY
}

\author{
MONA A. A. ABDEL RAHMAN ${ }^{1}$; SOAD A. NASEF ${ }^{2}$ and ENGY A. HAMED ${ }^{3}$ \\ ${ }^{1}$ Reference Laboratory for Veterinary Quality Control on Poultry Production, Nadi El-Seid \\ Street, Dokki P.O. Box 246, Giza 12618, Egypt, Email: Drmonaali2000@yahoo.com \\ ${ }^{2}$ Animal Health Research Institute, Nadi El-Seid Street, Dokki P.O. Box 246, Giza 12618, Egypt \\ ${ }^{3}$ Ministry of Agriculture, Nadi El-Seid Street, Dokki P.O. Box246, Giza 12618, Egypt
}

Received: 28 June 2017; $\quad$ Accepted: 30 July 2017

\begin{abstract}
Salmonella Kentucky has an increasing world wide spread among human and animals which causes a great problem. Twenty six Salmonella Kentucky strains isolated from different samples during 2011 - 2016, twenty two from chicken and four from quail. In the present work we study the genetic diversity through screening of 11 virulence genes genes $(i n v \mathrm{~A}, \operatorname{avr\mathrm {A}}, s s a \mathrm{Q}, \operatorname{mgt} \mathrm{C}, \operatorname{sii} \mathrm{D}, \operatorname{sop} \mathrm{B}, \operatorname{sip\mathrm {A}}, \operatorname{sod} \mathrm{C} 1, \operatorname{sop} \mathrm{E} 1, \operatorname{sp} v \mathrm{C}$, and $b c f \mathrm{C})$ by $\mathrm{PCR}$. The invA were detected in $100 \%$ of the Salmonella strains; but $92.3 \%$ of strains carry sopB, $88.4 \%$ of strains were carry $a v r \mathrm{~A}, b c f \mathrm{C}$ and $s s a \mathrm{Q}, m g t \mathrm{C}(80.7 \%), \operatorname{sop} \mathrm{E}$ and $\operatorname{sod} \mathrm{C}(19.2 \%), \operatorname{sil} \mathrm{D}(11.5 \%), s p v \mathrm{C}(3.8 \%)$, while no one carry gipA. These results show the presence of virulence genes in Salmonella Kentucky with potential poultry and public health hazard.
\end{abstract}

Key words: Salmonella, Salmonella Kentucky, avrA, ssaQ, virulence genes.

\section{INTRODUCTION}

Salmonella is a major zoonotic pathogen in Europe, causing approximately 152,000 confirmed human infections in 2007 (Anonymous, 2009).

Salmonellosis is world wide spread among human and animals caused by different serovars belong to Salmonella enterica subspp. Enterica as Enteritidis, Typhimurium, Newport, and Javiana, Salmonella Kentucky ST198 has an increasing multiple drug resistant which consequently showing it has a public health hazard (LeHello et al., 2011).

Food and Safety Inspection Service (FSIS), from 2000 to 2009 reported that Salmonella Kentucky, Enteritidis, Heidelberg and Typhimurium are commonly found in broilers and ground chicken (Andino and Hanning, 2015).

Most virulence genes of Salmonella are clustered in regions distributed over the chromosome called Salmonella pathogenicity islands (SPI) (van Asten and van Dijk, 2005).

Corresponding author: Dr. MONA A. A. ABDEL RAHMAN E-mail address: Drmonaali2000@yahoo.com

Present address: Reference Laboratory for Veterinary Quality Control on Poultry Production, Nadi El-Seid Street, Dokki P.O. Box246, Giza 12618, Egypt
These gene-clusters might be acquired by Salmonella from other species through horizontal gene transfer, this hypothesis is based on the significant difference in GC content of the islands compared to that of the residual genome and the remnants of bacteriophages or transposon insertion sequences that often mark the borders of the islands (van Asten and van Dijk, 2005).

Amplification of invA gene now has been recognized as an international standard for detection of Salmonella genus (Malorny et al., 2003).Invasion gene (invA) responsible for intestinal mucosa invasion by all Salmonellae (Fluit, 2005; Chuanchuen et al., 2010), this gene which is chromosomally located aids attachment of the pathogen to the epithelial cells (Galán and Curtiss, 1989).

The Sop proteins (sopA-E) (sop) and the heat-labile Salmonella enterotoxin (stn) are effector proteins that is integrated in pathogenesis of Salmonella through survival and replication (van Asten and van Dijk, 2005).

There are several virulence factors contributing to Salmonella adhesion and invasion mechanism, as Salmonella plasmid virulence ( $s p v)$ operon, which consists of five genes (spvRABCD), potentiates the systemic spread of the pathogen and aids in its replication in extra-intestinal sites (Zou et al., 2012). spvR is a positive regulatory protein essential for the expression of the other spv genes (Guiney et al., 
1995) while $s p v \mathrm{~B}$ product ADP-ribosylates actin, make imbalance of the eukaryotic cell (Lesnick et al., 2001). Experiments have shown that $s p v \mathrm{~B}$ together with $s p v \mathrm{C}$ is responsible for virulence to Salmonella Typhimurium when administered subcutaneously to mice (Matsui et al., 2001).

$m g t \mathrm{C}$ gene encodes $M g t \mathrm{~B} \mathrm{Mg} 2+$ transporter and helps Salmonella to survive within macrophages (Alix and Blanc-Potard, 2007).

The $\operatorname{sig} \mathrm{DE}$ operon encodes $\operatorname{Sig} \mathrm{D}(\operatorname{Sop} \mathrm{B})$, a multifaceted effector that is involved in many steps of pathogenesis (Fàbrega and Jordi, 2013).

While the fimbrial gene $b c f C$ has a role in cell invasion (Huehn et al., 2010). Induction of cell apoptosis to limit the host's inflammatory responses is mediated by the avrA gene (Borges et al., 2013).

Aim of this work is to determine the extent to which virulence genes $(i n v \mathrm{~A}, a v r \mathrm{~A}, s s a \mathrm{Q}, m g t \mathrm{C}, \operatorname{sil} \mathrm{D}, s o p \mathrm{~B}$, $\operatorname{gip} \mathrm{A}, \quad \operatorname{sod} \mathrm{C} 1, \quad s p v \mathrm{C}, \quad \operatorname{sop} \mathrm{E} 1, \quad b c f \mathrm{C})$ existence in Salmonella Kentucky from avian origin that may pose a risk to the human population and poultry in Egypt.

\section{MATERIALS AND METHODS}

\section{Bacterial isolates:}

Collection of Salmonella Kentucky strains from July 2011 to May 2016 was done during routine examination of different samples submitted to reference laboratory for veterinary quality control on poultry production, a total of 26 Salmonella Kentucky strains were collected from internal organs, feed, embryonated eggs, drag swabs and paper lining chick box, twenty two from chicken and four from quail.

\section{Bacterial isolation and identification:}

The detection and identification of Salmonella isolates was done according to ISO 6579/cor.1.2004 and by serotyping of all the Salmonella isolates were done by slide agglutination using commercial $\mathrm{O}$ and $\mathrm{H}$ antisera (Difco Laboratories, Detroit, MI, USA) in accordance with the Kauffmann-White typing scheme and ISO/TR 6579-3:2014.

\section{Polymerase chain reaction $(\mathrm{PCR})$ :}

DNA extraction was performed using QIAamp DNA mini kit (Qiagen, Germany, GmbH Catalogue no.51304).

Oligonucleotide primer: primers were used supplied from metabion (Germany) and PCR conditions was mentioned as in Table (1).

All samples were confirmed by using Conventional PCR technique by using invA gene.

\section{Virulence gene detection:}

Conventional PCR technique was used for detection of virulence determinants by detection of 10 virulence genes $(a v r \mathrm{~A}, s s a \mathrm{Q}, m g t \mathrm{C}, \operatorname{sii} \mathrm{D}, \operatorname{sop} \mathrm{B}, \operatorname{gip} \mathrm{A}, \operatorname{sod} \mathrm{C} 1$, $s o p \mathrm{E} 1, \quad s p v \mathrm{C}$, and $b c f \mathrm{C})$ in the 26 Salmonella Kentucky strains by conventional PCR technique.

Isolates were purified on LB (luria-Bertani) agar and subsequently grown overnight at $37^{\circ} \mathrm{C}$ in $\mathrm{LB}$ broth.

PCR amplification: a volume of $25 \mu \mathrm{L}$ PCR reaction containing $12.5 \mu \mathrm{L}$ of Emerald Amp Max PCR Master Mix (Emerald, Japan), $1 \mu \mathrm{L}$ of each primer of $20 \mathrm{pmol}$ concentrations, $4.5 \mu \mathrm{L}$ of Depic water and 6 $\mu \mathrm{L}$ of template was used in a Biometra thermal cycler. The reference strains provided by the External Quality Assurance Services (EQAS) were used as positive controls of S. Kentucky. DNA of the negative control (E. coli NCIMB 50034).

\section{Analysis of the PCR products:}

The PCR products were separated by electrophoresis on 1\% agarose gel (Applichem, Germany, $\mathrm{GmbH}$ ) in $1 \mathrm{x}$ TBE buffer at room temperature using gradients of $5 \mathrm{~V} / \mathrm{cm}$. for gel analysis $5 \mu \mathrm{L}$ of the products was loaded in each gel slot. Gene ruler 100-1000 bp ladder. Thermo scientific was used to determine the fragment size. The gel was photographed using a gel documentation system (applied). 
Table 1: Virulence factor targets and primers, including nucleotide sequences, PCR conditions, and references.

\begin{tabular}{|c|c|c|c|c|c|c|c|}
\hline \multirow{2}{*}{$\begin{array}{c}\text { Gene } \\
\text { designation }\end{array}$} & \multirow{2}{*}{$\begin{array}{c}\text { Location } \\
\text { on SP1/gene function }\end{array}$} & \multirow{2}{*}{$\begin{array}{l}\text { Oligonucleotide } \\
\text { sequences }\left(5^{\backslash}-3^{\backslash}\right)\end{array}$} & \multicolumn{3}{|c|}{ PCR conditions ${ }^{a}$} & \multirow{2}{*}{$\begin{array}{l}\text { Product } \\
\text { Size (bp) }\end{array}$} & \multirow{2}{*}{ References } \\
\hline & & & Denaturing & Annealing & Extension & & \\
\hline \multirow[t]{2}{*}{$\operatorname{inv} \mathrm{A}$} & \multirow{2}{*}{$\begin{array}{l}\text { Type III secretion } \\
\text { system apparatus } \\
\text { SPI-1/invasion of } \\
\text { macrophages }\end{array}$} & $\begin{array}{l}\text { F: GTG AAA TTA TCG } \\
\text { CCA CGT TCG GGCAA }\end{array}$ & \multirow[t]{2}{*}{$\begin{array}{l}94^{\circ} \mathrm{C} \text { for } 60 \\
\text { seconds }\end{array}$} & \multirow[t]{2}{*}{$\begin{array}{l}64^{\circ} \mathrm{C} \text { for } 30 \\
\text { seconds }\end{array}$} & \multirow{2}{*}{$\begin{array}{l}72^{\circ} \mathrm{C} \text { for } \\
30 \\
\text { seconds }\end{array}$} & \multirow[t]{2}{*}{284} & \multirow[t]{2}{*}{$\begin{array}{l}\text { Salehi } \text { et } \\
\text { al., '2005 }\end{array}$} \\
\hline & & $\begin{array}{l}\text { R:TCA TCG CAC CGT } \\
\text { CAA AGG AACG }\end{array}$ & & & & & \\
\hline \multirow[t]{2}{*}{$a v r \mathrm{~A}$} & \multirow{2}{*}{$\begin{array}{c}\text { SPI-1/controls } \\
\text { Salmonella-induced } \\
\text { inflammation }\end{array}$} & $\begin{array}{l}\mathbf{F}: \text { CCT GTA TTG TTG } \\
\text { AGC GTC TGG }\end{array}$ & \multirow[t]{2}{*}{$\begin{array}{l}95^{\circ} \mathrm{C} \text { for } 30 \\
\text { seconds }\end{array}$} & \multirow[t]{2}{*}{$\begin{array}{c}58^{\circ} \mathrm{C} \text { for } 30 \\
\text { seconds }\end{array}$} & \multirow{2}{*}{$\begin{array}{c}72^{\circ} \mathrm{C} \text { for } \\
30 \\
\text { seconds }^{b}\end{array}$} & \multirow[t]{2}{*}{422} & \multirow[t]{2}{*}{$\begin{array}{c}\text { Huehn et } \\
\text { al., } 2010\end{array}$} \\
\hline & & $\begin{array}{l}\text { R:AGA AGA GCT TCG } \\
\text { TTG AAT GTCC }\end{array}$ & & & & & \\
\hline \multirow[t]{2}{*}{$\operatorname{ssa\mathrm {Q}}$} & \multirow{2}{*}{$\begin{array}{l}\text { SPI-2/secretion system } \\
\text { apparatus protein, } \\
\text { component of second } \\
\text { T3SS }\end{array}$} & $\begin{array}{l}\text { F:GAA TAG CGA ATG } \\
\text { AAG AGC GTCGTC C }\end{array}$ & \multirow[t]{2}{*}{$"$} & \multirow[t]{2}{*}{$"$} & \multirow[t]{2}{*}{$"$} & \multirow[t]{2}{*}{455} & \multirow[t]{2}{*}{$\begin{array}{c}\text { Huehn et } \\
\text { al., } 2010\end{array}$} \\
\hline & & $\begin{array}{l}\text { R:CAT CGT GTT ATC } \\
\text { CTC TGT CAG C }\end{array}$ & & & & & \\
\hline \multirow[t]{2}{*}{$m g t \mathrm{C}$} & \multirow[t]{2}{*}{ SPI-4/Mg ${ }^{2+}$ uptake } & $\begin{array}{l}\mathbf{F}: \text { TGA CTA TCA ATG } \\
\text { CTC CAG TGA AT }\end{array}$ & \multirow[t]{2}{*}{$\bar{l}$} & \multirow[t]{2}{*}{$"$} & \multirow[t]{2}{*}{$"$} & \multirow[t]{2}{*}{677} & $\begin{array}{c}\text { Huehn } \text { et } \\
\text { al., } 2010\end{array}$ \\
\hline & & $\begin{array}{l}\text { R:ATT TAC TGG CCG } \\
\text { CTA TGC TGT TG }\end{array}$ & & & & & \\
\hline $\begin{array}{c}\text { siiD } \\
(\text { Spi4D) }\end{array}$ & Type I secretion/SPI-4 & $\begin{array}{l}\mathbf{F}: \text { GAA TAG AAG ACA } \\
\text { AAG CGA TCA TC }\end{array}$ & $"$ & $"$ & $"$ & 655 & $\begin{array}{c}\text { Hauser et } \\
\text { al., } 2011\end{array}$ \\
\hline & & $\begin{array}{l}\text { R:GCT TTG TTC ACG } \\
\text { CCT TTC ATC }\end{array}$ & & & & & \\
\hline $\operatorname{sop} \mathrm{B}$ & $\begin{array}{c}\text { SPI-5/inositol } \\
\text { polyphosphate, } \\
\text { phosphatase that promotes }\end{array}$ & $\begin{array}{l}\text { F: TCA GAA GRC GTC } \\
\text { TAA CCA CTC }\end{array}$ & $"$ & $"$ & $"$ & 517 & $\begin{array}{l}\text { Huehn et } \\
\text { al., } 2010\end{array}$ \\
\hline & $\begin{array}{c}\text { macropinocytosis, } \\
\text { regulates } \\
\text { SCV localization, and } \\
\text { promotes } \\
\text { fluid secretion }\end{array}$ & $\begin{array}{l}\text { R:TAC CGT CCT CAT } \\
\text { GCA CAC TC }\end{array}$ & & & & & \\
\hline $\operatorname{gip} \mathrm{A}$ & $\begin{array}{c}\text { Gifsy-1 } \\
\text { bacteriophage/Peyer's }\end{array}$ & $\begin{array}{l}\text { F:ACG ACT GAG CAG } \\
\text { CGT GAG }\end{array}$ & " & " & " & 518 & $\begin{array}{l}\text { Huehn } \text { et } \\
\text { al., } 2010\end{array}$ \\
\hline & $\begin{array}{l}\text { patch-specific } \\
\text { virulence factor }\end{array}$ & $\begin{array}{l}\text { R:TTG GAA ATG GTG } \\
\text { ACG GTA GAC }\end{array}$ & & & & & \\
\hline $\operatorname{sod} \mathrm{C} 1$ & $\begin{array}{c}\text { Gifsy-2 } \\
\text { bacteriophage/periplasmic } \\
\mathrm{Cu}, \mathrm{Zn} \text {-superoxide }\end{array}$ & $\begin{array}{l}\text { F:CGG GCA GTG TTG } \\
\text { ACA AAT AAAG }\end{array}$ & $"$ & $"$ & $"$ & 424 & $\begin{array}{l}\text { Huehn et } \\
\text { al., } 2010\end{array}$ \\
\hline & dismutases & $\begin{array}{l}\text { R:TGT TGG AAT TGT } \\
\text { GGA GTC }\end{array}$ & & & & & \\
\hline sopE1 & $\begin{array}{c}\text { Cryptic } \\
\text { bacteriophage/promotes }\end{array}$ & $\begin{array}{l}\text { F:ACT CCT TGC ACA } \\
\text { ACC AAA TGC GGA }\end{array}$ & $"$ & $"$ & $"$ & 422 & $\begin{array}{l}\text { Huehn et } \\
\text { al., } 2010\end{array}$ \\
\hline & $\begin{array}{l}\text { membrane ruffling and } \\
\text { disrupts tight junctions }\end{array}$ & $\begin{array}{l}\text { R:TGT CTT CTG CAT } \\
\text { TTC GCC ACC }\end{array}$ & & & & & \\
\hline$s p v \mathrm{C}$ & $\begin{array}{c}\text { pSLT/A } \\
\text { phosphothreonine }\end{array}$ & $\begin{array}{l}\mathbf{F}: \text { ACC AGA GAC ATT } \\
\text { GCC TTC C }\end{array}$ & $"$ & $"$ & $"$ & 467 & $\begin{array}{l}\text { Huehn et } \\
\text { al., } 2010\end{array}$ \\
\hline & $\begin{array}{l}\text { lyase required for } \\
\text { complete } \\
\text { virulence in murine } \\
\text { models }\end{array}$ & $\begin{array}{l}\text { R:TTC TGA TCG CCG } \\
\text { CTA TTC G }\end{array}$ & & & & & \\
\hline$b c f C$ & $\begin{array}{l}\text { Chromosome/bovine } \\
\text { colonization factor, }\end{array}$ & $\begin{array}{l}\mathbf{F}: A C C \text { AGA GAC ATT } \\
\text { GCC TTC C }\end{array}$ & $\begin{array}{c}95^{\circ} \mathrm{C} \text { for } 30 \\
\text { seconds }\end{array}$ & $\begin{array}{c}53^{\circ} \mathrm{C} \text { for } 30 \\
\text { seconds }\end{array}$ & $\begin{array}{c}72^{\circ} \mathrm{C} \text { for } \\
30\end{array}$ & 467 & $\begin{array}{l}\text { Huehn et } \\
\text { al., } 2010\end{array}$ \\
\hline & fimbrial usher & $\begin{array}{l}\text { R:TTC TGC TCG CCG } \\
\text { CTA TTC G }\end{array}$ & & & seconds $^{\mathrm{b}}$ & & \\
\hline
\end{tabular}

a PCR was done for 35 cycles.

b After 30 cycles, final extension step of 4 minutes at $72^{\circ} \mathrm{C}$ was performed.

${ }^{\mathrm{c}} \mathrm{SCV}$, Salmonella-containing vacuole. 


\section{RESULTS}

\section{Bacterial isolates:}

A total of 26 Salmonella Kentucky strains; twenty two from chicken ( 2 drag swabs, 1 table eggs, 1 embryonated eggs, 6 internal organs, 2 feed, 10 paper lining chick box) and four from cloacal swabs from quail.

\section{Virulotyping:}

All isolates were screened using PCR analysis for the presence or absence of 11 selected virulence genes (Table 1). The invA were detected in $100 \%$ of the Salmonella strains; SopB 92.3\%. 88.4\% of strains were carry, avrA, bcfC and $s s a \mathrm{Q}, m g t \mathrm{C}(80.7 \%)$, sopE and $\operatorname{sod} \mathrm{C}(19.2 \%)$, siiD (11.5\%), spvC (3.8\%), while no one carry gipA.

Table 2: Distribution of the virulence genes among Salmonella Kentucky strains.

\begin{tabular}{|c|c|c|c|c|c|c|c|c|c|c|c|c|}
\hline No. & source & invA & mgtC & sopB & $a v r A$ & bcfC & $\operatorname{spvC}$ & sopE1 & $\operatorname{gip} \mathrm{A}$ & siiD & $\operatorname{ssa} Q$ & SodC1 \\
\hline 1 & chicken & + & + & + & + & + & - & - & - & - & + & - \\
\hline 2 & chicken & + & + & + & + & + & - & - & - & - & + & - \\
\hline 3 & chicken & + & + & + & + & + & - & - & - & - & + & + \\
\hline$\varepsilon$ & chicken & + & + & + & + & - & - & - & - & - & + & - \\
\hline 5 & chicken & + & - & + & + & - & - & - & - & - & - & - \\
\hline 6 & chicken & + & + & + & + & + & - & - & - & - & + & - \\
\hline 7 & chicken & + & + & + & + & + & - & - & - & - & + & - \\
\hline 8 & chicken & + & + & + & + & + & - & - & - & - & + & - \\
\hline 9 & chicken & + & + & + & + & + & - & - & - & - & + & + \\
\hline 10 & chicken & + & + & + & + & + & + & - & - & - & + & + \\
\hline 11 & chicken & + & + & + & + & + & - & - & - & - & + & + \\
\hline 12 & chicken & + & + & + & - & + & - & - & - & - & + & - \\
\hline 13 & chicken & + & + & + & + & + & - & - & - & - & + & - \\
\hline 14 & chicken & + & + & + & + & + & - & - & - & - & + & - \\
\hline 15 & chicken & + & + & + & + & + & - & - & - & - & - & - \\
\hline 16 & chicken & + & - & + & + & + & - & - & - & - & - & - \\
\hline 17 & chicken & + & + & + & + & + & - & + & - & + & + & - \\
\hline 18 & chicken & + & + & + & + & + & - & + & - & + & + & - \\
\hline 19 & chicken & + & + & + & + & + & - & + & - & - & + & - \\
\hline 20 & chicken & + & + & + & + & + & - & + & - & - & + & - \\
\hline 21 & chicken & + & - & + & + & + & - & - & - & - & + & - \\
\hline 22 & chicken & + & + & + & + & + & - & + & - & + & + & - \\
\hline 23 & Quail & + & - & - & - & - & - & - & - & - & + & - \\
\hline 24 & Quail & + & - & - & - & + & - & - & - & - & + & - \\
\hline 25 & Quail & + & + & + & + & + & - & - & - & - & + & - \\
\hline 26 & Quail & + & + & + & + & + & - & - & - & - & + & + \\
\hline \multicolumn{2}{|c|}{ Total } & 26 & 21 & 24 & 23 & 23 & 1 & 5 & 0 & 3 & 23 & 5 \\
\hline \multicolumn{2}{|r|}{$\%$} & 100 & 80.8 & 92.3 & 88.5 & 88.5 & 3.8 & 19 & 0 & 11.5 & 88.5 & 19 \\
\hline
\end{tabular}

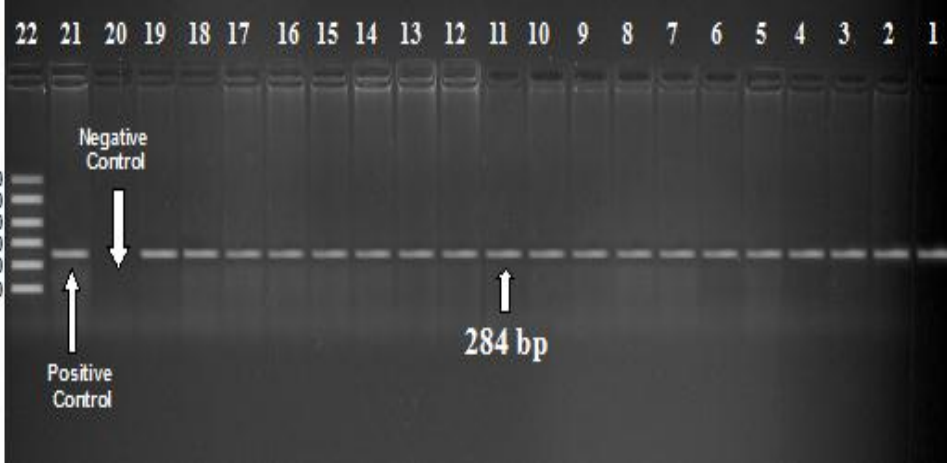

Photo (1). Agarose gel electrophoresis showing Salmonella specific PCR of Salmonella Kentucky using primer set for the $i n v A(284 \mathrm{bp})$ gene

Lanes 1 - 19: positive samples of Salmonella Kentucky

Lane 20: Negative control (E. coli NCIMB 50034)

Lane 21: Positive control (Salmonella Kentucky EQAS)

Lane 22: DNA ladder. 


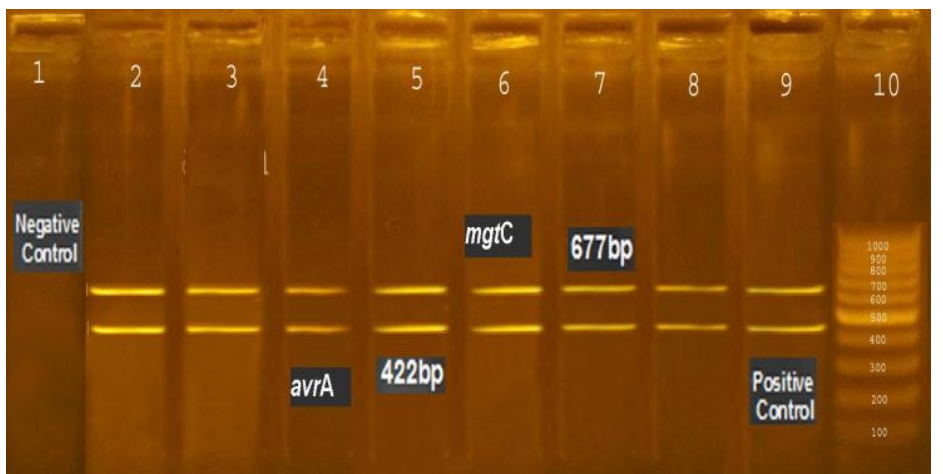

Photo (2): Agarose gel electrophoresis showing Duplex PCR with amplification of 422 bp and 677 bp bp fragments for $a v r A$ and $m g t C$ genes of Salmonella Kentucky performed with their specific primers

Lane 1: DNA ladder

Lane 2: Negative control (E. coli NCIMB 50034)

Lane 3: Positive control (Salmonella Kentucky EQAS)

Lanes 4-10: positive Salmonella Kentucky samples for avrA and $m g t \mathrm{C}$ genes

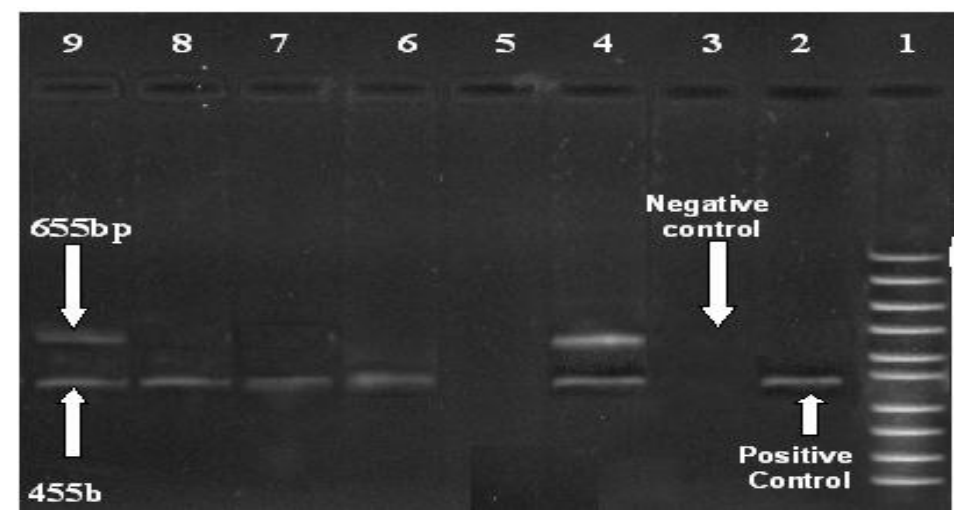

Photo (3): Agarose gel electrophoresis showing Duplex PCR with amplification of 455bp and 655bp fragments for $s s a Q$ and siiD genes of Salmonella Kentucky performed with their specific primer Lanes 1: DNA ladder

Lane 2: Positive control (Salmonella Kentucky EQAS)

Lane 3: Negative control (E. coli NCIMB 50034)

Lanes 4,9: positive Salmonella Kentucky samples for ssa $Q$ and siiD genes

Lanes 6,7,8: positive Salmonella Kentucky samples for ssaQ gene

Lane 5: Negative Salmonella Kentucky sample for ssaQ and siiD genes

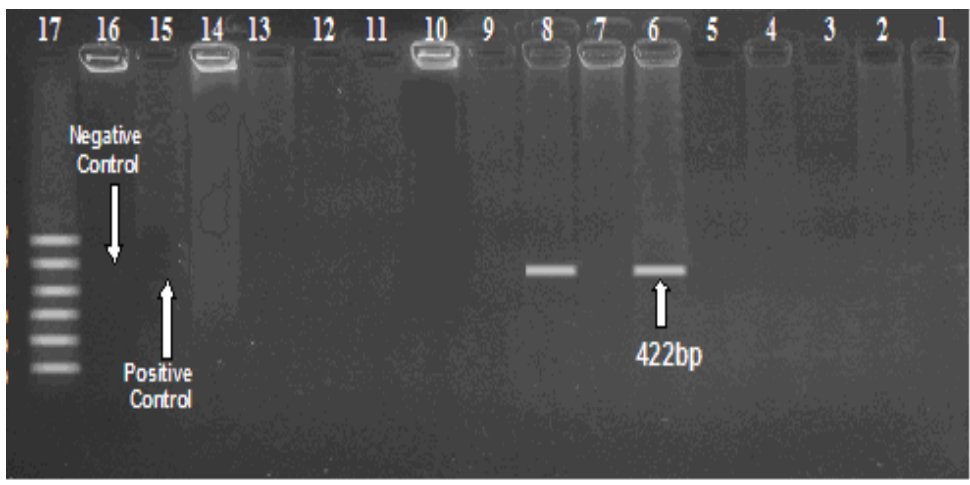

Photo (4): Agarose gel electrophoresis showing PCR amplification of the 422 bp SopE1 gene of Salmonella Kentucky.

Lanes 1-5, 7, 9-14: Negative Salmonella Kentucky samples for SopE1 gene

Lanes 6, 8: positive Salmonella Kentucky samples for SopE1 gene

Lane 15: Positive control (Salmonella Kentucky EQAS)

Lane 16: Negative control (E. coli NCIMB 50034)

lane17: DNA ladder 


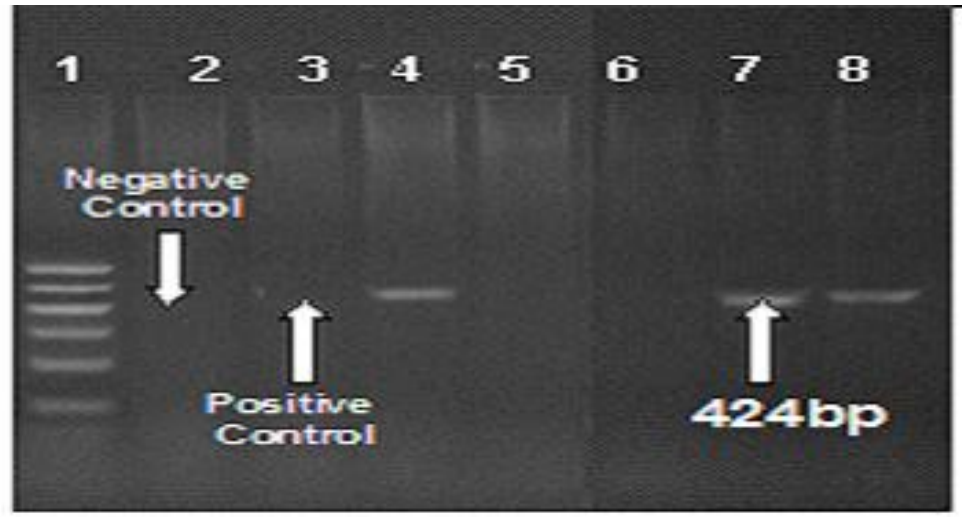

Photo (5): Agarose gel electrophoresis showing PCR with amplification of 424 bp gene SodC1 of Salmonella.

Lane 1: DNA ladder

Lane 2: Negative control (E. coli NCIMB 50034)

Lane 3: Positive control (Salmonella Kentucky EQAS)

Lanes 4, 7, 8: positive Salmonella Kentucky samples for SodC1 gene

Lane 5, 6: Negative Salmonella Kentucky sample for SodCl gene

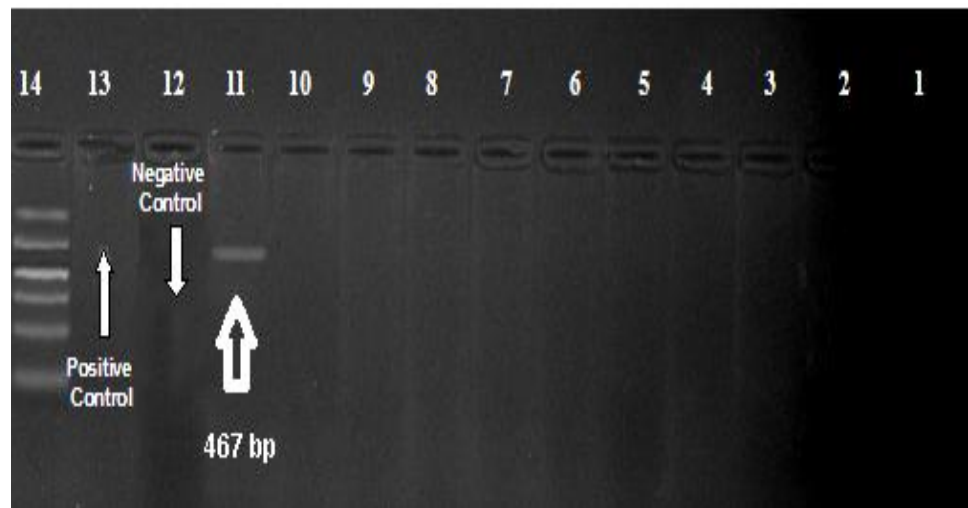

Photo (6): Agarose gel electrophoresis showing PCR with amplification of $467 \mathrm{bp}$ fragments for $s p v C$ gene of Salmonella Kentucky performed with the specific primer

Lanes 1-10: Negative Salmonella Kentucky samples for $s p v C$ gene

Lane 11: positive Salmonella Kentucky samples for $s p v C$ gene

Lane 12: Negative control (E. coli NCIMB 50034)

Lane 13: Positive control (Salmonella Kentucky EQAS)

Lane 14: DNA ladder

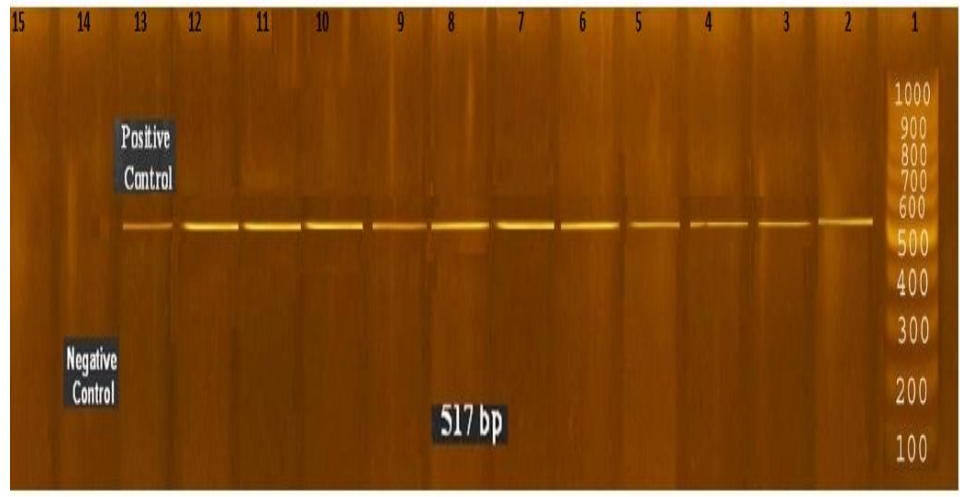

Photo (7): Agarose gel electrophoresis showing amplification product of $517 \mathrm{bp}$ fragments of $\operatorname{sopB}$ gene of Salmonella Kentucky performed with the specific primer

Lanes 1-12: positive Salmonella Kentucky samples for sopB gene

Lane 13: Positive control (Salmonella Kentucky EQAS)

Lane 14: Negative control (E. coli NCIMB 50034)

Lane 15: DNA ladder 


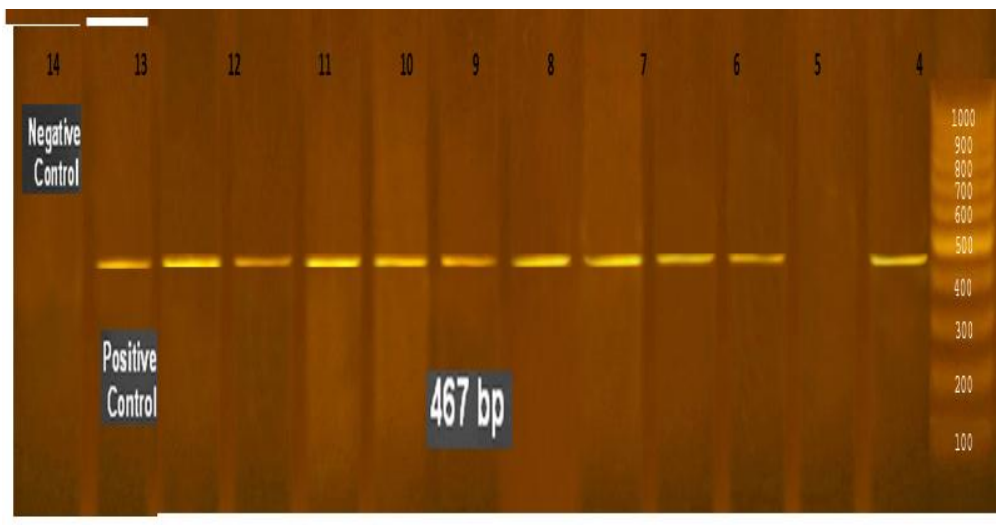

Photo (8): Agarose gel electrophoresis showing amplification product of $467 \mathrm{bp}$ fragments of $b c f C$ gene of Salmonella Kentucky performed with their primer.

Lanes 1: DNA ladder

Lanes 2,4-12: positive Salmonella Kentucky samples for $b c f C$ gene

Lane 3: Negative Salmonella Kentucky sample for $b c f C$ gene

Lane 13: Positive control (Salmonella Kentucky EQAS)

Lane 14: Negative control (E. coli NCIMB 50034)

Table 3: Distribution of virulence genes combinations in Salmonella Kentucky.

\begin{tabular}{|c|c|c|}
\hline No. & source & Virulence gene combinations \\
\hline 1 & chicken & invA mgtC sopB avrA bcfC ssaQ \\
\hline 2 & chicken & mgtC sopB avrA bcfC ssaQ invA \\
\hline 3 & chicken & invA mgtC sopB avrA bcfC ssaQ Sodc1 \\
\hline 4 & chicken & invA $m g t C \operatorname{sopB} a v r A s s a Q$ \\
\hline 5 & chicken & invA sopB sopB avrA \\
\hline 6 & chicken & invA $\operatorname{mgtC} \operatorname{sop} B$ avrA bcfC ssaQ \\
\hline 7 & chicken & invA mgtC sopB avrA bcfC ssaQ \\
\hline 8 & chicken & invA $m g t C$ sopB avrA bcfC ssaQ \\
\hline 9 & chicken & invA mgtC sopB avrA bcfC ssaQ Sodc1 \\
\hline 10 & chicken & mgtC sopB avrA bcfC spvC ssaQ Sodc1 invA \\
\hline 11 & chicken & invA mgtC sopB avrA bcfC ssaQ Sodc1 \\
\hline 12 & chicken & inv A mgtC sopB bcfC ssaQ \\
\hline 13 & chicken & invA $m g t C$ sopB avrA bcfC ssaQ \\
\hline 14 & chicken & invA $m g t C$ sopB avrA bcfC ssaQ \\
\hline 15 & chicken & invA mgtC sopB avrA bcfC \\
\hline 16 & chicken & invA sopB sopB avrA bcfC \\
\hline 17 & chicken & invA mgtC sopB avrA bcfC sopE1 siiD ssaQ \\
\hline 18 & chicken & invA mgtC sopB avrA bcfC sopE1 siiD ssaQ \\
\hline 19 & chicken & invA mgtC sopB avrA bcfC sopE1 ssaQ \\
\hline 20 & chicken & invA mgtC sopB avrA bcfC sopE1 ssaQ \\
\hline 21 & chicken & invA sopB avrA bcfC ssaQ \\
\hline 22 & chicken & invA sopB avrA bcfC sopE1 siiD ssaQ \\
\hline 23 & Quail & invA $s s a Q$ \\
\hline 24 & Quail & inv A $b c f C s s a Q$ \\
\hline 25 & Quail & invA mgtC sopB avrA bcfC ssaQ \\
\hline 26 & Quail & invA mgtC sopB avrA bcfC ssaQ Sodc1 \\
\hline
\end{tabular}




\section{DISCUSSION}

Both the presence and the dissemination of Salmonella spp. in foods represent an important issue to the poultry industry, since they could determine a decrease in the consumption of poultry meat, posing a threat to the national and international poultry trading (Ikuno et al., 2004).

S. Kentucky is widely distributed in broiler in America more over it has isolated from poultry and poultry products and it was of high antibiotic resistance ( Fricke et al., 2009).

S. Kentucky is isolated from several species hasn't any signs of illness as cattle, poultry, poultry products, environment and domesticated dogs in the United States (Haley et al., 2016 a) S. Kentucky ST198 is responsible for several human cases who were travel to Middle East, Southeast Asia or Africa (LeHallo et al., 2011, 2013 a,b).

Screening by PCR based on 11 well known virulence genes was applied. The results showed that variable dissemination percent among Salmonella kentucky (table 2). The results indicated that only little or no variation was found for genes incorporated in SPIs and for the fimbrial marker, which is in accordance with (Huehn et al., 2010) and assure that virulence genes are widely distributed among Salmonella serovars.

The variety of virulence factors among Salmonella serovars has resulted in differences in their pathogenicity (Fluit, 2005). The detection of invA gene in all the examined isolates is in agreement with previous reports in Egypt (Osman et al., 2013, 2014a, 2014b, Ahmed et al., 2016). and worldwide (Chuanchuen et al., 2010; Borges et al., 2013; Rowlands et al., 2014). The invA gene encodes for a protein in the inner and outer membrane, which is essential for the invasion of epithelial cells (Darwin and Miller, 1999). These studies described this gene as a marker for the molecular detection of Salmonella serotypes by PCR ( Salehi et al., 2005).

The invA gene, the $\operatorname{sop} B, b c f C, a v r \mathrm{~A}, s s a \mathrm{Q}$ and $m g t \mathrm{C}$ genes were present in the most of strains. On contrary, the gipA gene was absent from all Salmonella strains.

Based on the PCR with 11 most important virulence genes, the virulotyping results for tested Salmonella Kentucky strains show variable results (sopB (24\26), $a v r \mathrm{~A}, b c f \mathrm{C}$ and $s s a \mathrm{Q}(23 \backslash 26), m g t \mathrm{C}(21 \backslash 26)$, sop $\mathrm{E}$ and sodC (5\26), siiD (3\26), spvC (1\26), while no one carry gip A.

In our work $\operatorname{sop} \mathrm{B}, a v r \mathrm{~A}, s s a \mathrm{Q}, m g t \mathrm{C}, b c f \mathrm{C}$ have the highest recorded Percent of tested virulence genes that's nearly similar to (Huehn et al., 2010, Osman et al., 2014b).

avrA gene was detected also in $88.4 \%$ of the isolates. The high frequency of this gene is only observed in serovars that have a potential to cause severe salmonellosis in humans (Borges et al., 2013).

The inclusion and reassortment of such prophageassociated virulence genes may help Salmonella to change its behavior adaptation and acquire new changes. Also fimbriae are responsible for adhesion of bacterium to the cells. They are a set of fimbrial determinants (including $b c f$, agf, csg, fim, lpf, saf, stb, stf, and STM4595) which is common between Salmonella serovars and responsible for colonization of host cells. (Huehn et al., 2009).

The $s o p \mathrm{~B}$ gene associated with prophages was found in $92.3 \%$ of the examined isolates. Different studies have also reported the detection of that gene in almost all the Salmonella isolates from food and human origin (Borges et al., 2013; Ahmed et al., 2016).

There are other genes on prophage may have a role in virulence as the prophages Gifsy1, 2, and 3, Fels-1 and 2, and SopEF (Ehrbar and Hardt, 2005). The SPI1 secreted effectors SopE and SopE2 act as guanine nucleotide-exchange-factors (GEFs) for the small GTPases Cdc42 and Rac (Thomson et al. 2004) in present study was detected by $19 \%$ which is nearly low as in (Osman et al., 2014b).

SodC found in pathogenic Gram-negative and Grampositive bacteria (Sanjay et al., 2010). It is responsible for protecting the pathogens against superoxide radicals generated by inflammatory and phagocytic cells during infections has been emphasized, non-detection of sodC may be due to their low expression and/or the instability of the enzyme due to proteolysis (Sanjay et al., 2010).

The virulence plasmid gene $s p v \mathrm{C}$ was detected in the lowest percent among other virulence genes (Huehn et al., 2010).

gipA was absent in all strains as found in (Osman et al., 2014). gipA, is stimulated when the bacteria colonize the small intestine, after infection takes place several genes are elicited due to bacterial growth in Peyer's patch in small intestine (Stanley et al., 2000).

This study shows that virulence genes are widely distributed among Salmonella Kentucky which may pose as potential risk for poultry and human infections. Virulence genes are located on transmissible genetic elements as transposons, plasmids or bacteriophages or pathogenicity islands (Hacker et al., 1997). 
In conclusion, the presence of these entire virulence gene in Salmonella Kentucky explain the increase of rate of isolation of this serotype from human and animals allover the world.

\section{ACKNOWLEDGEMENTS}

We are very grateful to Omneya sarea, Abdelhafez Samir for their technical help.

\section{REFERENCES}

Ahmed, H.A.; El-Hofy, F.I.; Shafik, S.M.; Abdelrahman, M.A. and Elsaid, G.A. (2016): Characterization of Virulence-Associated Genes, Antimicrobial Resistance Genes, and Class 1 Integrons in Salmonella enterica serovar Typhimurium Isolates from Chicken Meat and Humans in Egypt. Foodborne Pathog Dis. Jun; 13(6):281-8. doi: 10.1089/fpd. 2015.2097.

Alix, E. and Blanc-Potard, A.B. (2007): mgtC: A key player in intramacrophage survival. Trends Microbiol;15: 252-256.

Andino, A. and Hanning, I. (2015): Salmonella enterica: Survival, Colonization, and Virulence Differences among Serovars. Scientific World Journal Volume, Article ID 520179, 1-16.

Anonymous (2009): The Community Summary Report on Trends and Sources of Zoonoses and Zoonotic Agents in the European Union in 2007. EFSA J; 223.

Borges, K.A.; Furian, T.Q.; Borsoi, A.; Moraes, H.L.S.; Salle, C.T.P. and Nascimento, V.P. (2013): Detection of virulence-associated genes in Salmonella Enteritidis isolates from chicken in South of Brazil. Pesquisa Veterina 'ria Brasileira; 33:1416-1422.

Chuanchuen, R.; Ajariyakhajorn, $K$. and Koowatananukul, C. (2010): Antimicrobial resistance and virulence genes in Salmonella enterica isolates from dairy cows. Foodborne Pathog Dis; 7: 63-69.

Darwin, K.H. and Miller, V.L. (1999): Molecular basis of the interaction of Salmonella with the intestinal mucosa. Clin Microbiol Rev 12, 405-428.

Ehrbar, K. and Hardt, W.D. (2005): Bacteriophageencoded type III effectors in Salmonella enterica subspecies 1 serovar Typhimurium. Infect Genet Evol; 5: 1-9.

Fàbrega, Anna and Jordi, Vila (2013): Salmonella enterica Serovar Typhimurium Skills To Succeed in the Host: Virulence and Regulation. Clinical Microbiology Reviews April Volume 26 Number 2. p. 308-341

Fluit, A.C. (2005): Towards more virulent and antibiotic-resistant Salmonella? FEMS Immunol Med Microbiol; 43: 1-11
Fricke, W.F.; McDermott, P.F.; Mammel, M.K.; Zhao, S.; Johnson, T.J. and Rasko, D.A. (2009): Antimicrobial resistance-conferring plasmids with similarity to virulence plasmids from avian pathogenic Escherichia coli strains in Salmonella enterica serovar Kentucky isolates from poultry. Appl. Environ. Microbiol. 75 (18): 5963 -71. Doi: 10.1128/AEM.00786-09.

Galán, J.E. and Curtiss, III. R. (1989): Cloning and molecular characterization of genes whose products allow Salmonella Typhimurium to penetrate tissue culture cells. Proc Nat Acad Sci USA 86, 6383-6387.

Guiney, D.G.; Fang, F.C.; Krause, M.; Libby, S.; Buchmeier, N.A. and Fierer, J. (1995): biology and clinical significance of virulence plasmids in Salmonella serovars. Clin. Infect. Dis. 21 (suppl. 2), S146-S151

Hacker, J.; Blum-Oehler, G.; Muhldorfer, I. and Tschape, H. (1997): Pathogenicity islands of virulent bacteria: structure, function and impact on microbial evolution. Mol Microbiol.;23:1089-97.

Haley, Bradd J.; Kim, Seon Woo; Pettengill James; Luo, Yan; Karns, Jeffrey S. and Van Kessel, Jo Ann S. (2016 a): Genomic and Evolutionary Analysis of Two Salmonella enterica Serovar Kentucky Sequence Types Isolated from Bovine and Poultry Sources in North America. PLOS ONE | DOI: 10.1371/journal. pone.0161225 October 3, (1-36).

Hauser, E.; Hebner, F.; Tietze, E.; Helmuth, R.; Junker, E. and Prager, R. (2011): Diversity of Salmonella enterica serovar Derby isolated from pig, pork and humans in Germany. Int $\mathrm{J}$. Food Microbiol. 2011;151: 141-9.

Huehn, S.; Bunge, C.; Junker, E.; Helmuth, R. and Malorny, B. (2009): Poultry associated Salmonella enterica subsp. enterica serovar 4,12: d:- reveals high clonality and a distinct pathogenicity gene repertoire. Appl Environ Microbiol; 75: 1011-1020.

Huehn, S.; La Ragione, R.M.; Anjum, M.; Saunders, M.; Woodward, M.J.; Bunge, C.; Helmuth, R.; Hauser, E.; Guerra, B.; Beutlich, J.; Brisabois, A.; Peters, T.; Svensson, L.; Madajczak, G.; Litrup, E.; Imre, A.; HerreraLeon, S.; Mevius, D.; Newell, D.G. and Malorny, B. (2010): Virulotyping and antimicrobial resistance typing of Salmonella enterica serovars relevant to human health in Europe. Foodborne Pathog Dis; 7: 523-535.

Ikuno, A.A.; Kanashiro, A.M.I.; Kiyota, S.; Castro, A.G.M. and Ferreira, V.C.A. (2004): Mutiplex PCR for accurate diagnosis of poultry infection by using Salmonella invA, sefA, $s p v \mathrm{C}$ genes sequences as molecular markers. Arq. Inst. Biol., 71: 265-267.

ISO (6579:2002/cor.1) (2004): Microbiology of food and animal feeding stuffs - Horizontal method 
for the detection of Salmonella. ISO 6579: 2002(E) International Standards Organization, Geneva

ISO/TR 6579-3: (2014): Microbiology of the food chain -- Horizontal method for the detection, enumeration and serotyping of Salmonella -Part 3: Guidelines for serotyping of Salmonella spp.

LeHello, S.; Bekhit, A.; Granier, S.; Barua, H.; Beutlich, J. and Zajac, M. (2013a): The global establishment of a highlyfluoroquinolone resistant Salmonella enterica serotype Kentucky ST198 strain. Frontiers in Microbiology 4.Dec 18;4: 395.

LeHello, S.; Harrois, D.; Bouchrif, B.; Sontag, L.; Elhani, D. and Guibert, V. (2013b): Highly drug-resistant Salmonella enterica serotype Kentucky ST198-X1: a microbiological study. Lancet Infect Dis. 13 (8): 672-9.

LeHello, S.; Hendriksen, R.S.; Doublet, B.; Fisher, I.; Nielsen, E.M. and Whichard, J.M. (2011): International spread of an epidemic population of Salmonella enterica serotype Kentucky ST198 resistant to ciprofloxacin. J. Infec Dis. 204: 675-684.

Lesnick, M.L.; Reiner, N.E.; Fierer, J. and Guiney, D.G. (2001): The Salmonella spvB virulence gene encodes an enzyme that ADPribosylates actin and destabilizes the cytoskeleton of eukaryotic cells. Mol. Microbiol. 39, 14641470.

Malorny, B.; Hoorfar, J.; Bunge, C. and Helmuth, $R$. (2003): Multicenter validation of the analytical accuracy of Salmonella PCR: towards an international standard. Appl Environ Microbiol 69, 290-296

Matsui, H.; Bacot, C.M.; Garlington, W.A.; Doyle, T.J.; Roberts, S. and Gulig, P.A. (2001). Virulence plasmid-borne $s p v \mathrm{~B}$ and $s p v \mathrm{C}$ genes can replace the 90 -kilobase plasmid in conferring virulence to Salmonella enterica serovar Typhimurium in subcutaneously inoculated mice. J. Bacteriol. 183, 4652-4658.

Ochman, H. and Groisman, E.A. (1996): Distribution of pathogenicity islands in Salmonella spp. Infect Immun 64, 5410-5412.

Osman, K.M.; Marouf, S.H. and Alatfeehy, N. (2013): Antimicrobial resistance and virulenceassociated genes of Salmonella enterica subsp. enterica serotypes Muenster, Florian, Omuna, and Noya strains isolated from clinically diarrheic humans in Egypt. Microb Drug Resist; 19: 370-377.

Osman, K.M.; Hassan, W.M. and Mohamed, R.A. (2014a): The consequences of a sudden demographic change on the seroprevalence pattern, virulence genes, identification and characterisation of integronmediated antibiotic resistance in the Salmonella enterica isolated from clinically diarrhoeic humans in Egypt. Eur. J. Clin. Microbiol. Infect. Dis.; 33: 13231337.

Osman, K.M.; Marouf, S.H.; Zolnikov, T.R. and AlAtfeehy, N. (2014b): Isolation and characterization of Salmonella enterica in dayold ducklings in Egypt. Pathog. Glob. Health; 108: 37-48.

Popoff, M.Y. (2001): Antigenic formulas of the Salmonella serovars, 8th edn. W. C. C. f. R. a. R. o. Salmonella, Paris: Institut Pasteur.

Rowlands, R.E.G.; Ristori, C.A.; Ikuno, A.A.; Barbosa, M.L.; Jakabi, M. and Franco, B.D.G.dM. (2014): Prevalence of drug resistance and virulence features in Salmonella spp. isolated from foods associated or not with salmonellosis in Brazil. Rev Inst Med Trop Sa o Paulo; 56: 461-467.

Sanjay, M.K.; Srideshikan, S.M.; Usha, M.S.; PhilipRaj, A.; Gaddad, S.M. and Shivannavar, C.T. (2010): Detection, amplification and sequence homology of sodC in clinical isolates of Salmonella sp. Indian. J. Med Res 131, April, pp 565-570.

Salehi, TZ.; Mahzounieh, M. and Saeedzadeh, A. (2005): Detection of InvA Gene in Isolated Salmonella from Broilers by PCR Method. Int J Poul Sci 4, 557-559.

Stanley, T.L.; Ellermeier, C.D. and Slauch, J.M. (2000): Tissue-specific gene expression identifies a gene in the lysogenic phage Gifsy1 that affects Salmonella enterica serovar typhimurium survival in Peyer's patches. J. Bacteriol. Aug; 182(16): 4406-13

Thomson, N.; Baker, S.; Pickard, D.; Fookes, M.; Anjum, M. and Hamlin, N. (2004): The role of prophage-like elements in the diversity of Salmonella enteric serovars. J Mol Biol; 339: 279-300

Van Asten, A.J. and Van Dijk, J.E. (2005): Distribution of "classic" virulence factors among Salmonella spp FEMS Immunology and Medical Microbiology 44. 251-259.

Zou, Ming; Keelara, Shivaramu and Thakur, Siddhartha (2012): Molecular Characterization of Salmonella enterica Serotype Enteritidis Isolates from Humans by Antimicrobial Resistance, Virulence Genes, and Pulsed-Field Gel Electrophoresis. Foodborne Pathog Dis.;9(3):232-8. doi: 10.1089/fpd.2011.1012. Epub 2012 Jan 27. 


\section{الكثف عن بعض جينات الضراوة للسالمونيلا كنتاكى المعزولة من الدواجن}

\section{منح على عبل الحليم عبل الرحمن ، سعاد عبل العزيز عبل الونبيس ناصف ، انجى أحد حامد بيومى}

Email: Drmonaali2000@yahoo.com Assiut University web-site: www.aun.edu.eg

تنتشر السالمونيلا كنتاكي بشكل متز ايد في جميع أنحاء العالم بين الإنسان و الحيو انات وهي تشكل مشكلة كبيرة. ولذا تم تجميع عدد ستة

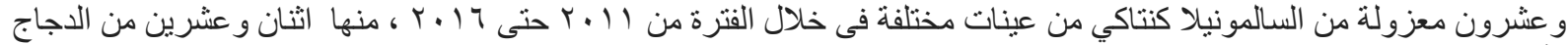

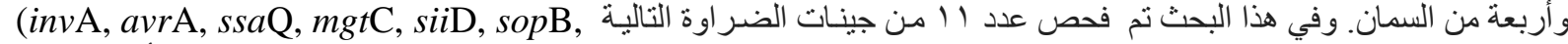
( gipA, sodC1, sopE1, spvC, bcfC

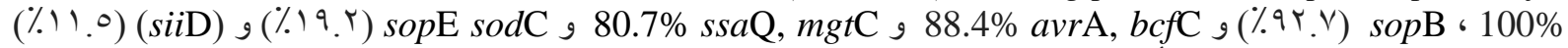

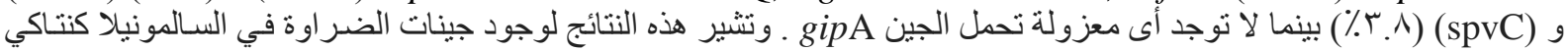

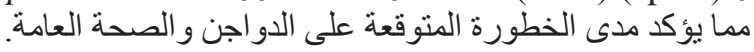

